\title{
Influence of Some Herbicides on the Chemical Composition of Cabernet Sauvignon Grapes and Wine
}

\author{
Tatyana Yoncheva $^{1 *}\left(\mathbb{C}\right.$, Neli Prodanova-Marinova2 ${ }^{(0)}$, Dimitar Dimitrov ${ }^{1}(\mathbb{C}$ \\ ${ }^{1}$ Agricultural Academy, Institute of Viticulture and Enology, Department of Vine Selection, Enology and Chemistry, \\ Pleven, Bulgaria \\ ${ }^{2}$ Agricultural Academy, Institute of Viticulture and Enology, Department of Vine Technologies and Plant Protection, \\ Pleven, Bulgaria
}

How to cite: Yoncheva, T., Prodanova-Marinova, N., \& Dimitrov, D. (2022). Influence of some herbicides on the chemical composition of Cabernet Sauvignon grapes and wine. Viticulture Studies (VIS), 2(1): 33- 43. https://doi.org/10.52001/vis.2022.9.33.43

\section{Article History:}

Received: 01.12.2021

Accepted: 06.01.2022

First online: 21.01.2022

\section{Corresponding Author} t ion@abv.bg

\begin{abstract}
The influence of the herbicides Pledge 50 VP, Lumax 538 SK and Guild, applied in a vineyard of Cabernet Sauvignon variety on the chemical composition of the grapes and the obtained wines was investigated in this study. The study was carried out in the period 2017-2019 with monitoring of the weather factors over the years. The treatment with herbicides was performed on an annual basis, during the last week of May, as they were introduced into the intra-row stripe once, with a backpack sprayer. For comparison, a non-herbicide treated control variant was used. The treated variants did not exceed the control for the sugar content of the grapes. The sugar ratio decreased in the order Control>V3 Guild>V2 Lumax 358 SK >V1 Pledge 50 VP. The most favorable in terms of sugar accumulation in grapes was 2019. The alcohol content of the wines was in correlation with the sugars in the grapes. Regarding the sugar-free extract in 2017 and 2018, with the exception of the variant treated with Pledge 50 VP, the rest exceeded the control, while in 2019 it had the highest rate. The total phenolic compounds in wines varied from $2.62 \pm 0.84$ to $2.73 \pm 0.93 \mathrm{~g} \mathrm{~L}^{-1}$. Their change increased in the order Control<Pledge $50 \mathrm{VP}<$ Lumax 358 SK<Guild. In 2018 and 2019 the control was with the lowest rates of anthocyanins while in 2017 only the variant treated with Guild exceeded it. No negative effect of the tested herbicides on the organoleptic profile of the obtained wines was established in the dose in which they were applied.
\end{abstract}

\author{
Keywords \\ Herbicides \\ Grapes \\ Wine \\ Chemical composition
}

\section{Introduction}

Wine quality and characteristics have been determined strongly dependent on features of the grapes. High quality wines have been obtained only from grapes with good sanitary indicators, in optimal technological maturity and with appropriate sugar accumulation.

The high yields of pure and quality grape and wine production largely depended on the grapevine protection from diseases, pests and weeds that require the proper and timely implementation of plant protection measures in the vineyards. In modern viticultural practice, many plant protection products based on various active substances had been used. The main requirements of them were high efficiency, harmlessness to man, no negative impact on the alcoholic fermentation, wine quality, etc. Their achievement depended on the meteorological conditions of the year, the nature of the active substance, the number and terms of treatment, etc. (Atanasov et al., 2005; Yoncheva et al., 2005).

The application of herbicides had been increasingly used in agricultural practice and in particular in viticulture, as an effective way to control unwanted vegetation. Along with the huge economic efficiency, their application led to some negative phenomena - suppression or complete destruction of a number of microorganisms in the soil, as well as changes in the soil ecosystem (Bakalivanov, 1982; Encheva, 1997; Popov et al., 2009; Hristeva et al., 2015; Zaller et al., 2018), increasing the number of resistant weed species (Dermency and Gasquez, 1990; Nandula et al., 2005; Shrestha et al., 2010; Alcorta et al., 2011), accumulation of the not 
decomposed amounts in soils, waters, and plants (Encheva, 1997; Lièvre-Muzard et al., 1998; Shiavon, 1998). The agricultural land pollution and accumulation of residues in vine plants had created a risk of toxicity both for the vines themselves and consumer of the products obtained from them (Tourte et al., 2008).

In this aspect, the effect of pesticide residues originating from various plant protection products applied in viticulture on grape and wine composition and quality had been interesting. These products did not usually cause changes in the grape composition, but had a different effect on the alcoholic fermentation. That mainly affected the reproductive ability and fermentation activity of wine yeast. Pesticide residues, depending on their composition and concentration, might have a stimulating, suppressive or completely inhibitory effect by altering the metabolism or inhibiting the cell enzyme systems (Trifonova et al., 2004; Yoncheva et al., 2005; Yoncheva et al., 2006; Oliva et al., 2007; Caboni and Cabras, 2010; Ortiz et al., 2010; Vallejo et al., 2017). In the winemaking process, the pesticide ratio in the final product got down by $40-100 \%$, compared to grapes (Katerova, 2007; Ortiz et al., 2010). This was a result of their decomposition, the course of the absorption processes, sedimentation, as well as the application of specific oenological practices in the grapes processing. They might affect to varying degrees the content of various components from the wine chemical composition, as well as to cause deviations in the organoleptic characteristics (Cabras and Angioni, 2000; Caboni and Cabras, 2010; Ortiz et al., 2010; Vallejo et al., 2017). Some fungicidal residues, for example, altered the phenolic composition of wines and their antioxidant activity (Oliva et al., 2009).

Regarding the influence of the herbicides on the composition and quality of grapes and wine, the published data have been insufficient and varying. For the active substances included in the present study, the main researches had been focused on glyphosate and flumioxazin, the most commonly used in the vineyards. According to Hatzidimitriou et al. (1996) flumioxazin caused changes in the water balance of the vine and reduced the carbohydrate content that deteriorated the wine quality. Applied in the soil, the same herbicide led to stress reduction in leaf carbohydrates, a decrease in free amino acids, which could affect the vine vitality for a long-term (Saladin et al., 2003). On the other hand, a study of the effect of indaziflam and flumioxazin on the varieties Sunbelt, Carlos, Triumph, Summit found that the quality of grapes (extract, titratable acidity and $\mathrm{pH}$ ) was not affected by the application of these herbicides (Basinger et al., 2019).

Glyphosate had been one of the most widely used herbicide in agriculture due to its efficacy. It was found that its application on the Ancellotta variety (Vitis vinifera L.) had resulted in a decrease in $\mathrm{pH}$ and an increase in titratable acids in grapes, compared to the untreated control, while the amount of anthocyanins, flavonoids and phenolic acids in wine did not change (Anonymous, 2016; Donnini et al., 2016). Glyphosate gave high yields, comparability in the chemical composition of grape juice from treated and untreated variants and lack of sensory differences in Cabernet Franc wine (Karl et al., 2016). According to other studies, glyphosate inhibited yeast growth, but that negative effect might be overcome with nitrogen fertilization (Morozova et al., 2017).

The effect of s-metolachlor, terbuthylazine, mesotrione and pyraflufen-ethyl individually and in various combinations on the grapes quality and the products obtained from their processing had not been explained.

The objective of this study was to determine the effect of the single foliar application, at a later date, of the herbicides Pledge 50 VP, Lumax SK and Guild on the composition and characteristics of grapes and wine from Cabernet Sauvignon variety, grown in the soil and climatic conditions of Central Northern Bulgaria.

\section{Material and Methods}

The trial was carried out in the period 2017 - 2019 in a vineyard of Cabernet Sauvignon variety grown at the Experimental Base of the Institute of Viticulture and Enology (IVE), Pleven, Central Northern Bulgaria. The experimental vineyard was established in 2003, with a space between the rows of $2.5 \mathrm{~m}$ and a distance in the row of $1.3 \mathrm{~m}$. The vines were grafted on a Berlandieri x Riparia rootstock, Selection Openhaim 4, with a modified Moser 
Table 1. Herbicides, doses and time of application

\begin{tabular}{|c|c|c|c|c|}
\hline $\begin{array}{c}\text { Trail } \\
\text { variant }\end{array}$ & $\begin{array}{c}\text { Herbicides applied } \\
\text { (formulated product) }\end{array}$ & $\begin{array}{c}\text { Time of } \\
\text { application }\end{array}$ & $\begin{array}{c}\text { Active substance } \\
\left(\mathrm{g} \mathrm{L}^{-1} ; \mathrm{g} \mathrm{kg}^{-1}\right)\end{array}$ & $\begin{array}{l}\text { Doses } \\
\left(\mathrm{L} \mathrm{da}^{-1}\right)\end{array}$ \\
\hline $\mathrm{V} 1$ & Pledge $50 \mathrm{VP}$ & postem & $500 \mathrm{~g} \mathrm{~kg}^{-1}$ flumioxazin & 0.02 \\
\hline V2 & Lumax 538 SK & postem & $\begin{array}{l}\quad 375 \mathrm{~g} \mathrm{~L}^{-1} \mathrm{~s} \text {-metolachlor }+125 \mathrm{~g} \mathrm{~L}^{-1} \\
\text { terbuthylazine }+337.5 \mathrm{~g} \mathrm{~L}^{-1} \text { mesotrione }\end{array}$ & 0.60 \\
\hline V3 & Guild & postem & $\begin{array}{l}1.71 \mathrm{~g} \mathrm{~L}^{-1} \text { pyraflufen-éthyl }+261 \mathrm{~g} \mathrm{~L}^{-1} \\
\text { glyphosate }\end{array}$ & 0.56 \\
\hline
\end{tabular}

training. Each variant covered 30 vines.

The change of the main climatic indicators (precipitation and air temperature), during the study period, was recorded by the meteorological station METOS WEATHER data $000003 \mathrm{CA}$, located on the territory of the Experimental Base.

\section{Herbicides Application}

The herbicides Pledge 50 VP, Lumax 538 SK and Guild were used in the study. The composition, their doses of application and the trial variants are presented in Table 1.

The treatment was carried out every year, once in the last week of May, when most dicotyledonous weeds were in the budding phase - the onset of flowering. The herbicides were introduced into the intra-row stripe once, with a backpack sprayer, at a consumption rate of working solution $400 \mathrm{~L} \mathrm{ha}^{-1}$ and the nozzle pressure Pmax $300 \mathrm{kPa}$. For comparison, a control variant $(C)$ not treated with herbicides was used.

\section{Vinification}

Every year during the ripening period of the grapes the dynamics of sugar accumulation was monitored and upon reaching technological maturity the grapes were harvested. The grapes were processed in the Experimental Wine Cellar of IVE according to the classical technology for making of red dry wines (Yankov, 1992) crumbling, crushing, sulphating (50 mg kg-1 $\left.\mathrm{SO}_{2}\right)$, adding pure culture of dry wine yeast Saccharomyces cerevisiae $\left(20 \mathrm{~g} \mathrm{hL}^{-1}\right)$ and a fermentation temperature of $28^{\circ} \mathrm{C}$.

After the completion of the alcoholic fermentation the obtained red wines were decanted and further sulphated to $30 \mathrm{mg} \mathrm{L}^{-1}$ free $\mathrm{SO}_{2}$.

\section{Chemical and Organoleptic Analysis}

The grapes chemical composition was determined by the following methods (Ivanov et al., 1979): sugars, $\mathrm{g} \mathrm{L}^{-1}$ - Dujardin hydrometer; glucose and fructose, $\mathrm{g} \mathrm{L}^{-1}$ - iodometric method; titratable acids (TA), $\mathrm{g} \mathrm{L}^{-1}$ - titration with $\mathrm{NaOH}$; malic and tartaric acid, $\mathrm{g} \mathrm{L}^{-1}$ - method of Pochinok; $\mathrm{pH}$ - $\mathrm{pH}$-meter; glucoacidimetric index (GAI) - calculation method, as sugars (\%) and $\mathrm{TA}\left(\mathrm{g} \mathrm{L}^{-1}\right)$ ratio.

The main indicators of the wines' chemical composition were analyzed according to the generally accepted methods in wine practice (Ivanov et al., 1979): alcohol, vol. \% - distillation method, Gibertini distillation apparatus with densitometer by distillate density; sugars, $\mathrm{g} \mathrm{L}^{-1}$ Schoorl method; total extract, $\mathrm{g} \mathrm{L}^{-1}-$ Gibertini distillation apparatus with densitometer, by density of the non-alcoholic sample; sugar-free extract (SFE), $\mathrm{g} \mathrm{L}^{-1}$ - calculation method (the difference between the total extract (TE) and sugars); titratable acids, $\mathrm{g} \mathrm{L}^{-1}$ - titration with $\mathrm{NaOH}$; volatile acids, $\mathrm{g} \mathrm{L}^{-1}$ - distillation method with subsequent titration with $\mathrm{NaOH}$; $\mathrm{pH}-\mathrm{pH}$ meter; total phenolic compounds (TPC), $\mathrm{g} \mathrm{L}^{-1}$ method of Singleton et Rossi; monomer anthocyanins, $\mathrm{mg} \mathrm{L}^{-1}$ - method of Singleton et Rossi by changing the $\mathrm{pH}$; spectral characteristics of the colour - intensity I [abs. units] - Somers method and tint T [abs. units] Glories method.

The experimental wines from each vintage were evaluated by the tasting commission of IVE - Pleven in order to determine the influence of the applied herbicides on their organoleptic characteristics and finding out of side, atypical aromas and flavors.

\section{Statistical Analysis}

The presented experimental results for the 
grapes and wines composition express the arithmetic mean value of two similar samples. In the cases a significant difference in the rates of the analyzed indicator was found, a third sample was made and the two closest values were taken into account.

The data from the analyses for the studied period were subjected to statistical processing, represented by mean value and standard deviation ( \pm SD). Excel 2007 (Microsoft Office) was used for the determination.

\section{Results and Discussion}

\section{Climatic Characteristics of the Study Period}

The first year of the experiment (2017) was marked as the most extreme in terms of climate. It is characterized by higher temperature amplitude - high summer and low winter temperatures (up to $-17.25^{\circ} \mathrm{C}$ ). The precipitation rate was more than the subsequent two years of the study. The maximum temperatures in June and August had reached $39.03^{\circ} \mathrm{C}$ and $39.56{ }^{\circ} \mathrm{C}$. In July the highest temperature for the year was recorded as $43.28{ }^{\circ} \mathrm{C}$ and the highest precipitation rate - a total of $210.4 \mathrm{~mm}$, while in June a small amount atypical for the region was noted (Figure 1). In total, in 2017, the precipitation rate was $946.8 \mathrm{~mm}$, which was the highest for the study period.

In 2018, no negative average monthly temperatures were reported (Figure 2). Although August had the highest average monthly temperature, the hottest day was registered in June $\left(35.71^{\circ} \mathrm{C}\right)$. The minimum average monthly temperature was in January, and the absolute minimum was recorded in March $\left(-14.1^{\circ} \mathrm{C}\right)$. The precipitation rate was less than the previous year $(801.6 \mathrm{~mm})$, with the main rainfall falling in June and July.

The last year of the study period in terms of temperature did not differ significantly from the previous one (Figure 3). The lowest temperatures, the average monthly $\left(-0.24{ }^{\circ} \mathrm{C}\right)$ and the minimum $\left(-14.29^{\circ} \mathrm{C}\right)$, were registered in January, and the highest - in August, the average monthly $24.87^{\circ} \mathrm{C}$ and the maximum $38.5^{\circ} \mathrm{C}$. The precipitation rate was $646.2 \mathrm{~mm}$, concentrated mainly in May, June and September.

There were few investigations and not much had been known about the impacts caused by herbicides on the grapes and wine quality (Zaller et al., 2018).

During the study period, the influence of the herbicides Pledge 50 VP, Lumax 538 SK and Guild, applied in the Cabernet Sauvignon vineyard, on the composition and characteristics of the grapes and experimental wines was monitored. The impact of the weather conditions

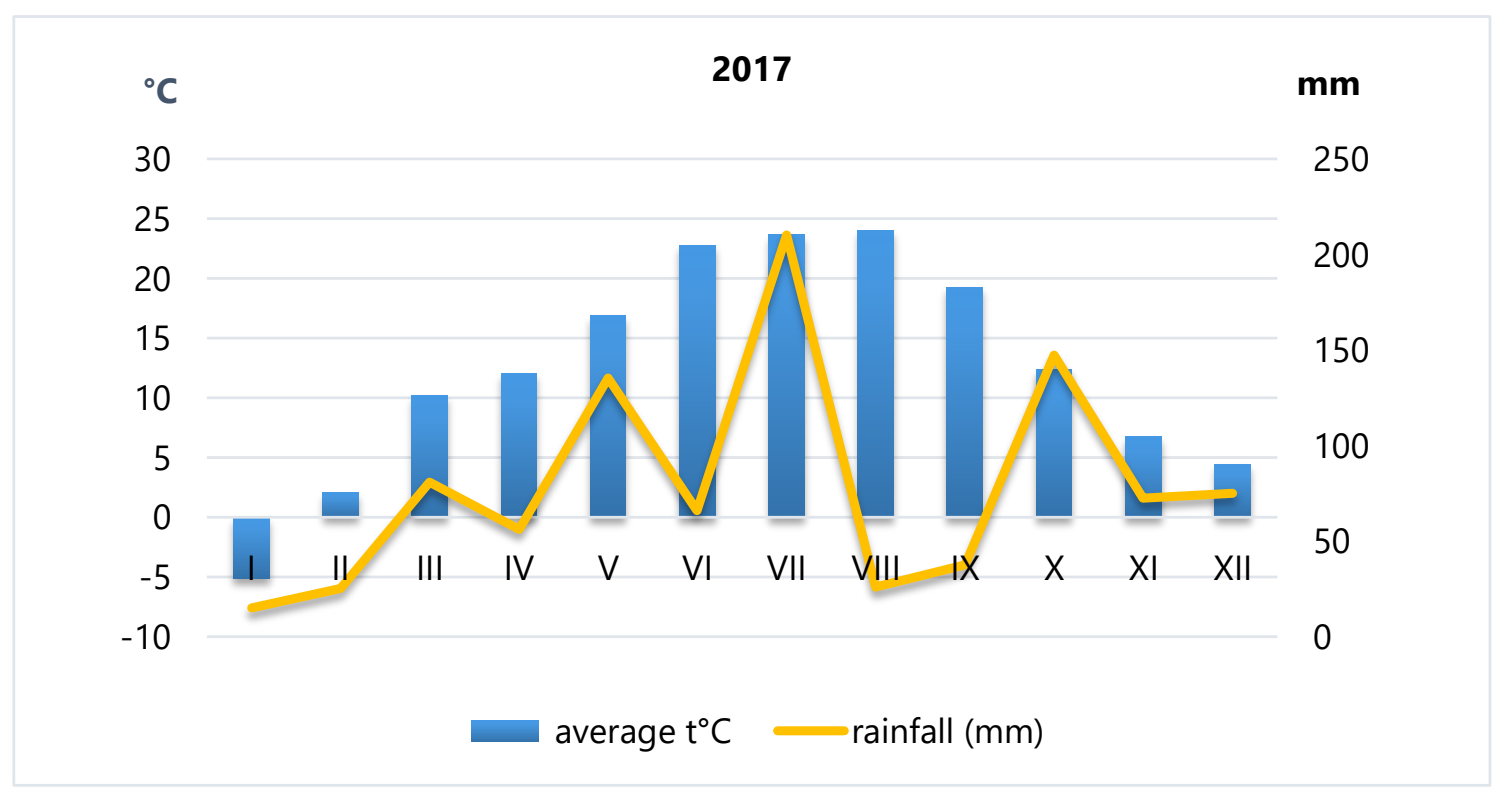

Figure 1. Climatic characteristics of 2017. 


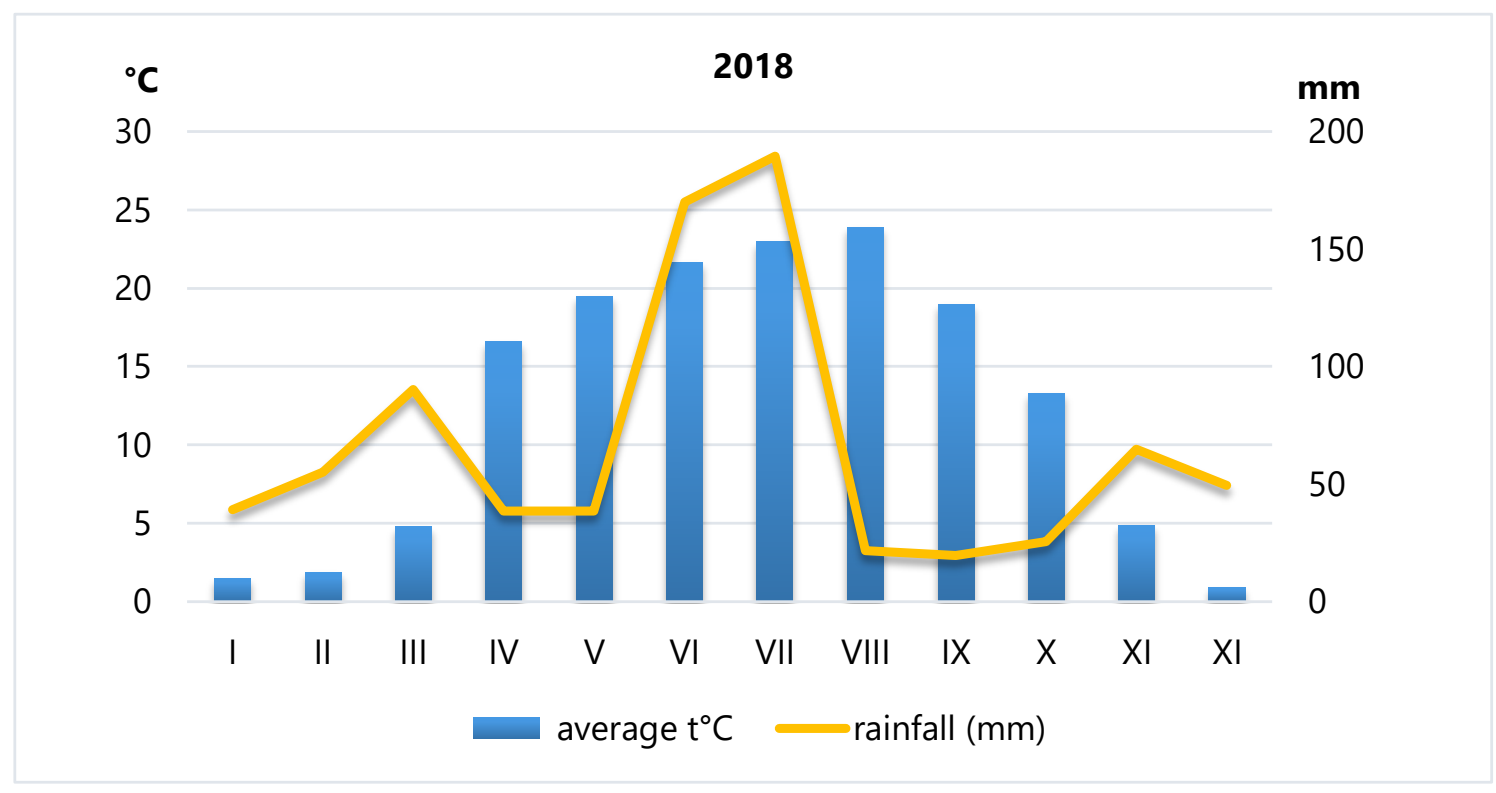

Figure 2. Climatic characteristics of 2018.

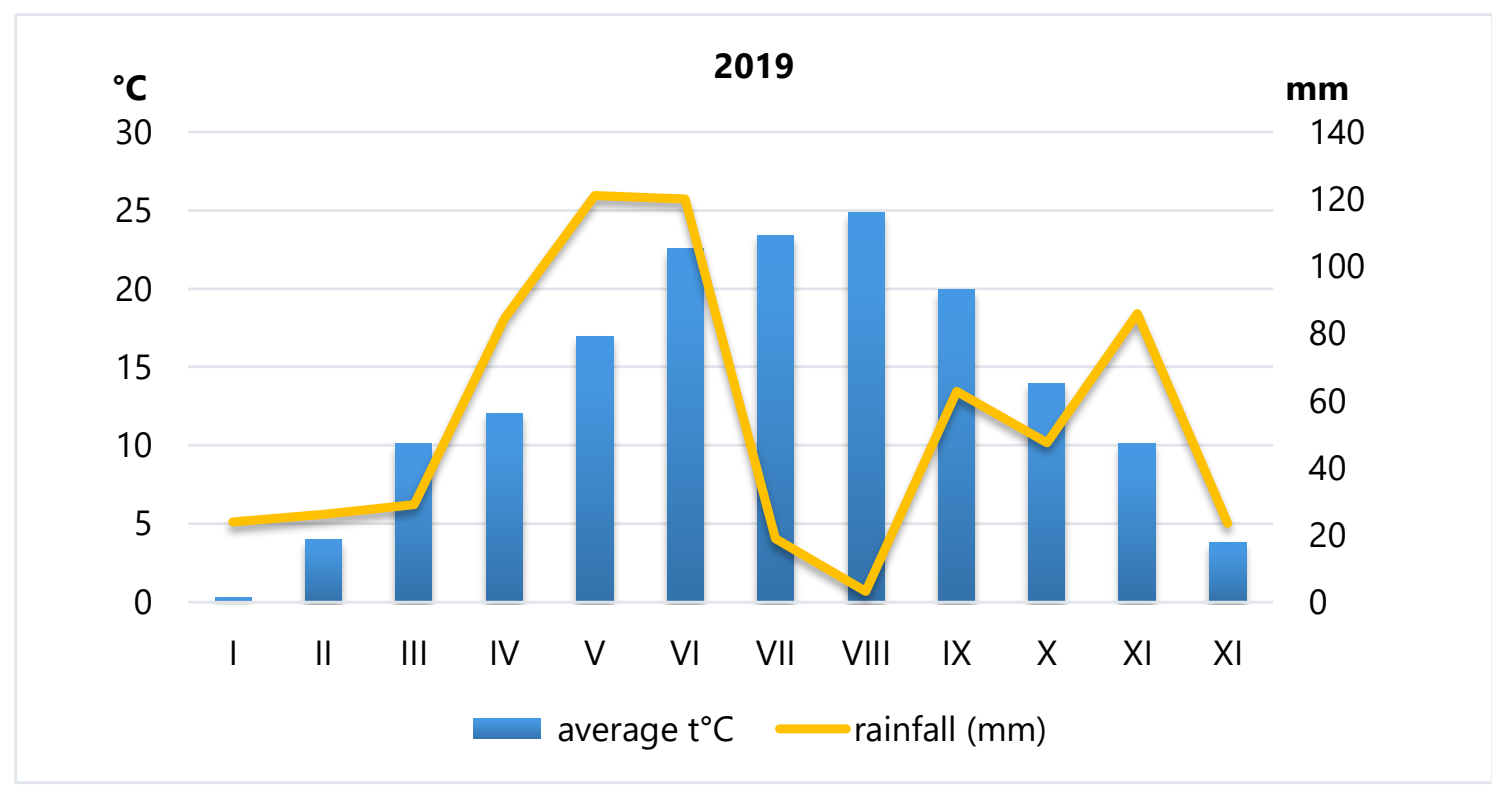

Figure 3. Climatic characteristics of 2019.

of the year on the products' quality from the three consecutive vintages was also reported.

\section{Chemical Composition of Grapes}

Available experimental data from other research showed that if pesticides were used as indicated by manufacturers no residues higher than those set by law and no negative effect at the time of harvest should appear (Ortiz et al., 2010).
Regarding to the influence of glyphosate (one of the most commonly used herbicides) no differences in grape berry weight or total soluble solids (i.e. Brix) were found. Their levels were basically the same as the control (Anonymous, 2016).

In the present research the grapes chemical composition from the experimental plantation, treated with the tested herbicides for the study period, is presented in Table 2 . 
The data showed that the year 2019 was the most favorable in terms of sugar accumulation. Grapes from all experimental variants had the highest rate of sugars, glucose and fructose. Grapes from the 2018 harvest had the lowest content, although the two years were close in terms of climate. During the study period, the experimental variants treated with the tested herbicides did not exceed the untreated control in sugar content. The sugars ratio in the grapes decreased in the order Control (mean 243.67 $\pm 16.26 \mathrm{~g} \mathrm{~L}^{-1}$ ) > V3, Guild (mean $233.00 \pm 22.60 \mathrm{~g} \mathrm{~L}^{-1}$ ) > V2, Lumax $358 \mathrm{SK}$ (mean 232.33 $\pm 18.19 \mathrm{~g} \mathrm{~L}^{-1}$ ) > V1, Pledge $50 \mathrm{VP}$ (mean $227.00 \pm 18.52 \mathrm{~g} \mathrm{~L}^{-1}$ ). From the determined monosaccharides glucose and fructose, a quantitative predominance of the fructose was found as their ratio was less than 1 . The highest content of fructose was reported in the control (mean $151.63 \pm 9.18 \mathrm{~g} \mathrm{~L}^{-1}$ ), and of glucose in V3 (mean $93.16 \pm 9.43 \mathrm{~g} \mathrm{~L}^{-1}$ ). The lowest amount of monosaccharides was recorded in V1 (fructose) and V2 (glucose), respectively.

The sugar content of the variants from the 2017 vintage varied from 228.00 (V1) to 247.00 (C) $\mathrm{g} \mathrm{L}^{-1}$. As for the sugar accumulation the control was followed by the grapes from V2 and V3. The highest content of fructose was determined in $C$, followed by $V 2$, while of glucose - in V3 and V2. In 2018, the sugars in the grapes per variants were in the range of 208.00 $(\mathrm{V} 1, \mathrm{~V} 3)$ to 226.00 (C) $\mathrm{g} \mathrm{L}^{-1}$. The control had the highest amount of fructose and V1 of glucose. In the 2019 vintage, the maximum ratio of sugars was also reported in the control variant $(258.00$ $\left.\mathrm{g} \mathrm{L}^{-1}\right)$. In the rest variants it varied from 243.00 (V2) to 252.00 (V3) $\mathrm{g} \mathrm{L}^{-1}$. The control had the best sugar accumulation, followed by V3. In these samples, respectively, the amount of glucose and fructose was higher.

As for the titratable acids in the grapes, there was a tendency in the experimental variants the lowest rates to be reported in the 2017 harvest and the highest in 2018. Except V2 Lumax 358 SK, in its mean value the control $\left(5.80 \pm 1.13 \mathrm{~g} \mathrm{~L}^{-1}\right)$ was exceeded by V1 Pledge 50 VP $\left(5.98 \pm 1.02 \mathrm{~g} \mathrm{~L}^{-1}\right)$ and V3 Guild $\left(6.05 \pm 0.58 \mathrm{~g} \mathrm{~L}^{-}\right.$ $\left.{ }^{1}\right)$. From the determined organic acids in the must, malic acid was predominant over tartaric acid. The malic acid content varied on the average from $4.54 \pm 0.92$ to $4.85 \pm 1.78 \mathrm{~g} \mathrm{~L}^{-1}$, with all experimental variants exceeding the control. The opposite trend was observed for tartaric acid. Its amount was the highest in the control (mean $3.44 \pm 1.62 \mathrm{~g} \mathrm{~L}^{-1}$ ) and the lowest in V2 Lumax $358 \mathrm{SK}$ (mean $2.83 \pm 1.43 \mathrm{~g} \mathrm{~L}^{-1}$ ). The $\mathrm{pH}$

Table 2. Chemical composition of Cabernet Sauvignon grapes for the period 2017-2019

\begin{tabular}{|c|c|c|c|c|c|c|c|c|c|}
\hline \multirow[b]{2}{*}{ Variants } & \multirow[b]{2}{*}{ Vintage } & \multicolumn{8}{|c|}{ Indicators } \\
\hline & & $\begin{array}{c}\text { Sugar, } \mathbf{g} \\
\mathrm{L}^{-1}\end{array}$ & $\begin{array}{c}\text { Glucose, } \\
\text { g L L }^{-1}\end{array}$ & $\begin{array}{c}\text { Fructose, } \\
\mathrm{g} \mathrm{L}^{-1}\end{array}$ & $\begin{array}{c}\text { Titratable } \\
\text { acids, } \\
\text { g L L }^{-1}\end{array}$ & $\begin{array}{c}\text { Tartaric } \\
\text { acids, } \\
\text { g L }^{-1}\end{array}$ & $\begin{array}{c}\text { Malic } \\
\text { acids, } \\
\text { g L L }^{-1}\end{array}$ & pH & GAI \\
\hline \multirow{6}{*}{$\begin{array}{c}\mathrm{C} \\
\text { (control) }\end{array}$} & 2017 & 247.00 & 89.46 & 157.54 & 4.50 & 1.83 & 4.16 & 3.46 & 5.48 \\
\hline & 2018 & 226.00 & 84.94 & 141.06 & 6.53 & 5.06 & 5.59 & 3.27 & 3.46 \\
\hline & 2019 & 258.00 & 101.70 & 156.30 & 6.38 & 3.44 & 3.86 & 3.45 & 4.04 \\
\hline & mean & 243.67 & 92.03 & 151.63 & 5.80 & 3.44 & 4.54 & 3.39 & 4.33 \\
\hline & $\pm S D$ & \pm 16.26 & \pm 8.67 & \pm 9.18 & \pm 1.13 & \pm 1.62 & \pm 0.92 & \pm 0.11 & \pm 1.04 \\
\hline & 2017 & 228.00 & 89.46 & 138.54 & 4.80 & 1.45 & 4.50 & 3.47 & 4.75 \\
\hline \multirow{4}{*}{$\begin{array}{c}\text { V1 } \\
\text { (Pledge } \\
50 \text { VP) }\end{array}$} & 2018 & 208.00 & 88.77 & 119.23 & 6.60 & 5.17 & 5.69 & 3.29 & 3.15 \\
\hline & 2019 & 245.00 & 100.80 & 144.20 & 6.53 & 3.59 & 3.76 & 3.44 & 3.75 \\
\hline & mean & 227.00 & 93.01 & 133,99 & 5.98 & 3.40 & 4.65 & 3.40 & 3.88 \\
\hline & $\pm S D$ & \pm 18.52 & \pm 6.75 & \pm 13.09 & \pm 1.02 & \pm 1.87 & \pm 0.97 & \pm 0.10 & \pm 0.81 \\
\hline \multirow{6}{*}{$\begin{array}{c}\text { V2 } \\
\text { (Lumax } \\
538 \text { SK) }\end{array}$} & 2017 & 243.00 & 90.45 & 152.55 & 5.03 & 1.79 & 4.03 & 3.46 & 4.83 \\
\hline & 2018 & 211.00 & 78.43 & 132.57 & 6.30 & 4.46 & 6.13 & 3.39 & 3.35 \\
\hline & 2019 & 243.00 & 100.80 & 141.20 & 5.55 & 2.24 & 3.96 & 3.42 & 4.36 \\
\hline & mean & 232.33 & 89.89 & 142.11 & 5.63 & 2.83 & 4.71 & 3.42 & 4.18 \\
\hline & $\pm \mathrm{SD}$ & \pm 18.19 & \pm 11.20 & \pm 10.02 & \pm 0.64 & \pm 1.43 & \pm 1.23 & \pm 0.04 & \pm 0.76 \\
\hline & 2017 & 239.00 & 93.15 & 145.85 & 5.33 & 1.68 & 4.14 & 3.44 & 4.48 \\
\hline \multirow{4}{*}{$\begin{array}{c}\text { V3 } \\
\text { (Guild) }\end{array}$} & 2018 & 208.00 & 83.74 & 124.26 & 6.68 & 4.12 & 6.87 & 3.30 & 3.11 \\
\hline & 2019 & 252.00 & 102.60 & 149.40 & 6.15 & 3.09 & 3.53 & 3.47 & 4.10 \\
\hline & mean & 233.00 & 93.16 & 139.84 & 6.05 & 2.96 & 4.85 & 3.40 & 3.90 \\
\hline & $\pm S D$ & \pm 22.60 & \pm 9.43 & \pm 13.61 & \pm 0.68 & \pm 1.22 & \pm 1.78 & \pm 0.09 & \pm 0.71 \\
\hline
\end{tabular}


values varied in a narrow range on the average from $3.39 \pm 0.11$ to $3.42 \pm 0.04$ and corresponded to the titratable acidity in the samples.

The titratable acids of the variants from the 2017 harvest varied from 4.50 to $5.33 \mathrm{~g} \mathrm{~L}^{-1}$, and all experimental variants exceeded the control. The acidity increased in the order Control < V1 Pledge 50 VP < V2 Lumax 358 SK $<$ V3 Guild. Quantitatively, the malic acid was almost twice as much as the tartaric acid, and the difference in their content between the samples was insignificant. The same trend was observed for $\mathrm{pH}$ values that were close. The grapes from the 2018 vintage that had the lowest sugar accumulation for the period, were characterized by the highest titratable acids - from 6.30 (V2) to 6.68 (V3) $\mathrm{g} \mathrm{L}^{-1}$, as V1 and V3 exceeded the control. The highest content of tartaric (from 4.12 to $5.17 \mathrm{~g} \mathrm{~L}^{-1}$ ) and malic acid (from 5.59 to $6.87 \mathrm{~g} \mathrm{~L}^{-1}$ ) was found in the samples from that year. The amount of malic acid in the experimental variants surpassed the control, while for the tartaric acid that was reported only in $\mathrm{V} 1$. The differences in $\mathrm{pH}$ values were insignificant, within the range $3.27-3.39$. In the 2019 harvest, despite the highest sugar concentration in the grapes for the period, higher titratable acids were also analyzed. Their content in the control was $6.38 \mathrm{~g} \mathrm{~L}^{-1}$, exceeded only by $\mathrm{V} 1\left(6.53 \mathrm{~g} \mathrm{~L}^{-1}\right)$. With the exception of $\mathrm{V} 2$ Lumax 358 SK, where the difference was almost double, in the other samples it was insignificant between the amount of tartaric and malic acid. The $\mathrm{pH}$ values between the different variants were similar.

In other research was found that the treatment with different herbicides resulted differently to change of $\mathrm{pH}$ and titratable acids of grapes. Their values could not be affected by the application of the herbicides (Basiinger et al., 2019) or could lead to a decrease in $\mathrm{pH}$ and an increase in titratable acids (Anonymous, 2016).

The glucoacidimetric indicator (GAl) was calculated for the grapes from all experimental samples, as it gave information about its quality and determined the purpose of its use. For the period, the GAl values were high and varied on the average from $3.88 \pm 0.81$ (V1 Pledge $50 \mathrm{VP}$ ) to $4.33 \pm 1.04(C)$, showing that the grapes from all experimental variants had an optimal chemical composition for making of wines of good chemical and tasting properties. The highest rates for this indicator were determined in the grapes from the 2017 vintage, followed by the 2019, and the lowest were in the 2018 harvest. In 2017 and 2018 the GAl of the control exceeded that of the other variants, while in 2019 V2 Lumax 358 SK and V3 Guild had the highest values.

\section{Chemical Composition of the Experimental Wines}

The residues of pesticides in grapes, musts and wines could influence on fermentation and organoleptic characteristics of wine. The type of wine and the correct use of oenotechnological processes influenced the disappearance or elimination of pesticide residues. There were not significant differences in the general chemical parameters of wine but it was found the influence of some pesticides on the aromatic composition of wine, mainly between the levels of major volatile - ethyl acetate, methanol, isobutanol and diethylacetal (Ortiz et al., 2010; Anonymous, 2016).

In the present study after the completion of the alcoholic fermentation, the experimental wines were analyzed for the main chemical indicators presented in Table 3.

The mean value of alcoholic content of the samples varied from $12.93 \pm 0.99$ (V1) to $13.76 \pm 0.61$ vol. \% (C). It was the highest in the control, which corresponded to the sugars in the grapes. The gradation in the alcoholic concentration of the wines was in correlation with the established sugar accumulation in grapes - Control > V3 Guild > V2 Lumax 358 SK $>$ V1 Pledge 50 VP. The experimental variants, the 2019 harvest had the highest alcohol (from 14.07 to $14.53 \mathrm{vol}$. \%) while the lowest were from the 2018 (from 12.27 to 13.28 vol. \%).

The pesticide residues on grapes could be transferred to the must and influenced the development of yeast strains. Their presence could affect yeast metabolic activity (Caboni and Cabras, 2010). Some pesticides had specific influence that derived from their mechanism of action. Glufosinate ammonium strongly impacts yeast physiology. Even small amounts of this herbicide caused a delay in yeast growth and grape juice fermentation (Vallejo et al., 2017).

The experimental data of the research about the chemical analysis of the residual 
Table 3. Chemical composition of the experimental wines Cabernet Sauvignon, for the period 2017-2019

\begin{tabular}{|c|c|c|c|c|c|c|c|c|c|c|c|c|c|c|}
\hline \multirow[b]{2}{*}{ Variants } & \multirow[b]{2}{*}{$\begin{array}{l}0 \\
\stackrel{\Xi}{ \pm} \\
\stackrel{\Xi}{5}\end{array}$} & \multicolumn{12}{|c|}{ Indicators } & \multirow[b]{2}{*}{ I } \\
\hline & & 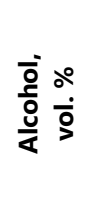 & ڤั & 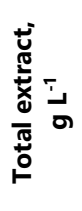 & 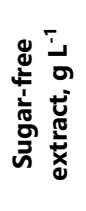 & 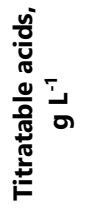 & 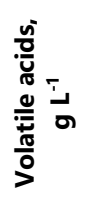 & 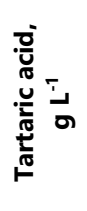 & 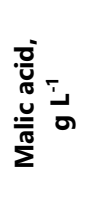 & هَ' & 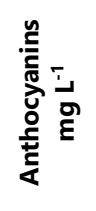 & 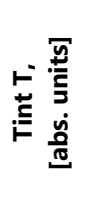 & 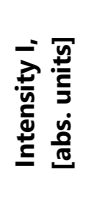 & \\
\hline \multirow{5}{*}{$\begin{array}{c}\text { C } \\
\text { (Control) }\end{array}$} & 2017 & 13.56 & 1.67 & 30.80 & 29.13 & 4.43 & 0.60 & 1.23 & 3.69 & 3.46 & 325.07 & 0.69 & 10.67 & 3.39 \\
\hline & 2018 & 13.28 & 1.93 & 24.30 & 22.37 & 5.33 & 0.65 & 1.49 & 4.55 & 1.78 & 232.37 & 0.88 & 9.72 & 3.40 \\
\hline & 2019 & 14.45 & 3.20 & 31.20 & 28.00 & 6.23 & 0.80 & 1.56 & 3.56 & 2.61 & 374.73 & 0.76 & 10.20 & 3.49 \\
\hline & mean & 13.76 & 2.27 & 28.77 & 26.50 & 5.33 & 0.68 & 1.43 & 3.93 & 2.62 & 310.72 & 0.78 & 10.20 & 3.43 \\
\hline & $\pm S D$ & \pm 0.61 & \pm 0.82 & \pm 3.87 & \pm 3.62 & \pm 0.90 & \pm 0.10 & \pm 0.17 & \pm 0.54 & \pm 0.84 & \pm 72.26 & \pm 0.10 & \pm 0.47 & \pm 0.05 \\
\hline \multirow{6}{*}{$\begin{array}{c}\text { V1 } \\
\text { (Pledge } \\
50 \text { VP) }\end{array}$} & 2017 & 12.43 & 1.71 & 27.90 & 26.19 & 4.68 & 0.52 & 1.19 & 3.76 & 3.09 & 315.13 & 0.61 & 10.24 & 3.32 \\
\hline & 2018 & 12.28 & 2.17 & 25.60 & 23.43 & 4.65 & 0.58 & 1.26 & 3.96 & 2.06 & 274.08 & 0.87 & 10.53 & 3.40 \\
\hline & 2019 & 14.07 & 3.20 & 30.40 & 27.20 & 6.35 & 0.82 & 1.64 & 3.70 & 2.89 & 400.42 & 0.75 & 10.59 & 3.45 \\
\hline & mean & 12.93 & 2.36 & 27.97 & 25.61 & 5.23 & 0.64 & 1.36 & 3.81 & 2.68 & 329.88 & 0.74 & 10.45 & 3.39 \\
\hline & $\pm \mathrm{SD}$ & \pm 0.99 & \pm 0.76 & \pm 2.40 & \pm 1.95 & \pm 0.97 & \pm 0.16 & \pm 0.24 & \pm 0.14 & \pm 0.55 & \pm 64.45 & \pm 0.13 & \pm 0.19 & \pm 0.06 \\
\hline & 2017 & 13.51 & 1.61 & 30.90 & 29.29 & 5.00 & 0.56 & 1.38 & 4.13 & 3.44 & 323.67 & 0.57 & 10.25 & 3.24 \\
\hline V2 & 2018 & 12.27 & 1.86 & 26.10 & 24.24 & 5.10 & 0.52 & 1.30 & 4.36 & 1.97 & 271.83 & 0.86 & 10.34 & 3.39 \\
\hline (Lumax & 2019 & 14.53 & 2.90 & 29.20 & 26.30 & 5.00 & 0.84 & 1.53 & 3.63 & 2.66 & 377.86 & 0.81 & 10.31 & 3.47 \\
\hline \multirow[t]{2}{*}{538 SK) } & mean & 13.44 & 2.12 & 28.73 & 26.61 & 5.03 & 0.64 & 1.40 & 4.04 & 2.69 & 324.45 & 0.75 & 10.30 & 3.37 \\
\hline & $\pm S D$ & \pm 1.13 & \pm 0.68 & \pm 2.43 & \pm 2.54 & \pm 0.06 & \pm 0.17 & \pm 0.12 & \pm 0.37 & \pm 0.73 & \pm 53.02 & \pm 0.15 & \pm 0.04 & \pm 0.12 \\
\hline \multirow{5}{*}{$\begin{array}{c}\text { V3 } \\
\text { (Guild) }\end{array}$} & 2017 & 13.16 & 2.05 & 32.00 & 29.95 & 5.23 & 0.62 & 1.26 & 4.43 & 3.66 & 408.64 & 0.57 & 10.96 & 3.26 \\
\hline & 2018 & 12.82 & 1.63 & 24.90 & 23.27 & 5.18 & 0.63 & 1.34 & 4.25 & 1.79 & 250.10 & 0.88 & 9.95 & 3.40 \\
\hline & 2019 & 14.40 & 2.59 & 29.90 & 27.31 & 6.08 & 0.80 & 1.49 & 3.79 & 2.74 & 384.16 & 0.79 & 10.44 & 3.46 \\
\hline & mean & 13.46 & 2.09 & 28.93 & 26.84 & 5.50 & 0.68 & 1.36 & 4.16 & 2.73 & 347.63 & 0.75 & 10.45 & 3.37 \\
\hline & $\pm \mathrm{SD}$ & \pm 0.83 & \pm 0.48 & \pm 3.65 & \pm 3.36 & \pm 0.50 & \pm 0.10 & \pm 0.12 & \pm 0.33 & \pm 0.93 & \pm 85.35 & \pm 0.16 & \pm 0.50 & \pm 0.10 \\
\hline
\end{tabular}

sugars ratio demonstrated that their quantity corresponded to the standards for dry wines making. The alcoholic fermentation in all samples took place completely, without deviations from the normal course and without a negative effect of the applied herbicides.

The content of the total and sugar-free extract was indicator of particular importance for the red wines' characteristics. They affected the taste by determining the wine density. There were no significant differences in their average amount between the experimental variants. Both indicators were interrelated and the highest mean value was reported in $\mathrm{V} 3$, respectively $28.93 \pm 3.65 \mathrm{~g} \mathrm{~L}^{-1}$ and $26.84 \pm 3.36 \mathrm{~g} \mathrm{~L}^{-1}$. The mean content of SFE ranged from $25.61 \pm 1.95$ (V1 Pledge $50 \mathrm{VP}$ ) to $26.84 \pm 3.36 \mathrm{~g} \mathrm{~L}^{-1}$ (V3 Guild), as except $V 1$, the other experimental variants exceeded the control. The 2017 vintage samples had the highest SFE (from 26.19 to $29.95 \mathrm{~g} \mathrm{~L}^{-1}$ ), followed by the 2019 harvest (from 26.30 to $28.00 \mathrm{~g} \mathrm{~L}^{-1}$ ), while the lowest were from the 2018 harvest (from 22.37 to $24.24 \mathrm{~g} \mathrm{~L}^{-1}$ ). No general trend was found in the value of this indicator, in the variants, during the three harvests. In 2017 (with the exception of V1) and in 2018 the rest variants exceeded the control quantitatively, while in 2019 it contained the most SFE.

The wine titratable acidity had been also an indicator affecting their taste and determining their freshness. The mean rates of the variants were close - from $5.03 \pm 0.06$ (V2 Lumax $358 \mathrm{SK}$ ) to $5.50 \pm 0.50 \mathrm{~g} \mathrm{~L}^{-1}$ (V3 Guild), as the control was surpassed only by $V 3$. The wines from the 2019 harvest had the highest titratable acidity (from 5.00 to $6.35 \mathrm{~g} \mathrm{~L}^{-1}$ ), and the lowest from the 2017 harvest (from 4.43 to $5.23 \mathrm{~g} \mathrm{~L}^{-1}$ ). There was no uniform trend in the change of acids in the samples from the three vintages. In 2017, all experimental variants contained more titratable acids compared to the control, as they were the most in V3 $\left(5.23 \mathrm{~g} \mathrm{~L}^{-1}\right)$. In 2018, the variants did not exceed the control and the lowest acidity was reported in V1 Pledge $50 \mathrm{VP}$ (4.65 $\left.\mathrm{g} \mathrm{L}^{-1}\right)$. In 2019, this variant had the highest rate $\left(6.35 \mathrm{~g} \mathrm{~L}^{-1}\right)$ and surpassed the control, while the lowest was in V2 Lumax 358 SK $\left(5.00 \mathrm{~g} \mathrm{~L}^{-1}\right)$.

The content of the malic and the tartaric acid in the experimental wines was also analyzed. Their reduction in relation to their quantity in the grapes was due to natural processes occurring during the winemaking. The tartaric acid decreased as a result of salts formation, which precipitated in the form of 
crystals, and the malic acid - due to the course of the malolactic fermentation (Chidi et al., 2018).

All experimental wines had normal volatile acidity with mean rates varying from $0.64 \pm 0.16$ to $0.68 \pm 0.10 \mathrm{~g} \mathrm{~L}^{-1}$. The samples from the 2019 harvest had more volatile acids.

The $\mathrm{pH}$ varied within the normal range for red wines. Its rates for the different variants and vintages were within close limits. On the average for the period they were in the range from $3.37 \pm 0.10$ to $3.43 \pm 0.05$.

Ortiz et al. (2010) established that regarding to the values of total acidity no significant differences with the control wine (with no phitosanitary treatment) existed. The same applied to the $\mathrm{pH}$. In some cases, there were differences from the control in volatile acidity and phenolic compounds content because the pesticide residues could influence their diffusion from the skin to the must during maceration.

The content of TPC, anthocyanins and the related to them colour features (intensity and tint) had been essential for the red wines quality. According to Oliva et al. (2009) study, the wine phenolic composition was altered in variable intensity by the presence of the pesticide residues.

The average rate of TPC in the experimental samples varied from $2.62 \pm 0.84$ to $2.73 \pm 0.93 \mathrm{~g} \mathrm{~L}^{-1}$. It was the lowest in the control, and the variants treated with herbicides exceeded it. The change of the TPC in the wines increased in the order Control < V1 Pledge 50 VP < V2 Lumax 358 SK < V3 Guild. All samples from the 2017 harvest contained the most TPC for the study period - from 3.09 (V1) to 3.66 (V3) $\mathrm{g} \mathrm{L}^{-1}$, as that year only $\mathrm{V} 3$ exceeded the control. The amount of phenolic substances was the lowest in the wines from the 2018 harvest - from 1.78 to $2.06 \mathrm{~g} \mathrm{~L}^{-1}$. For wines from the 2018 and 2019 vintages, the control had the lowest content of phenols, respectively $1.78 \mathrm{~g} \mathrm{~L}^{-1}$ and $2.61 \mathrm{~g} \mathrm{~L}^{-1}$, and it was surpassed by all herbicidetreated variants. Of these harvests, the amount of phenols in $\mathrm{V} 1$ wines was the highest, $2.06 \mathrm{~g} \mathrm{~L}^{-}$ ${ }^{1}$ and $2.89 \mathrm{~g} \mathrm{~L}^{-1}$, respectively.

The anthocyanins had been the components of the wine composition directly related to and determining the color of red wines. After glyphosate treatment some anthocyanins were found to be lower in grapes but in finished wines there were no significant differences in their content and other polyphenol levels (Anonymous, 2016).

On the average, anthocyanins values in the experimental samples varied within the range from $310.72 \pm 72.26$ (C) to $329.88 \pm 64.45$ $\mathrm{mg} \mathrm{L}^{-1}$ (V1 Pledge $50 \mathrm{VP}$ ), as the control was exceeded by all other variants. During the study period, wines from the 2019 harvest contained the most anthocyanins (from 374.73 to 400.42 $\left.\mathrm{mg} \mathrm{L}^{-1}\right)$, and from the 2018 vintage - the least (from 232.37 to $274.08 \mathrm{mg} \mathrm{L}^{-1}$ ). In both years, the lowest value was reported in the control, and the highest in V1. In 2017, V3 (408.64 $\mathrm{mg} \mathrm{L}^{-1}$ ) had significantly higher content of anthocyanins and was superior compared to the control.

The intensity and tint of the colour had been interrelated indicators of the color characteristics of red wines. In the experimental samples, their mean values were close and varied within narrow limits, respectively from $10.20 \pm 0.47$ to $10.45 \pm 0.50$ [abs. units] and from $0.74 \pm 0.13$ to $0.78 \pm 0.10$ [abs. units]. The control had the lowest mean intensity value and the highest for the tint. Although they were not distinguished for the highest anthocyanins content for the study period, the wines from the 2017 harvest had the highest intensity from 10.24 to 10.96 [abs. units], with only V3 Guild surpassing the control. The samples from the 2018 harvest had the weakest color characteristics - they had the lowest values of intensity from 9.72 to 10.53 [abs. units] and the highest for the tint from 0.86 to 0.88 [abs. units]. Every year an organoleptic characteristic of the wines from each harvest was performed by the tasting commission in IVE - Pleven. During the study period, no deviations in the aromatic and taste characteristics were found in the tasted samples. Therefore, the tested herbicides in the vineyard in the dose in which they were applied did not have a negative effect on the organoleptic profile of the wines and did not give them an atypical aromas or flavors.

\section{Conclusion}

Based on the obtained results and their analysis, it might be summarized:

The experimental variants treated with the tested herbicides in sugar content did not 
exceed the untreated control. The sugars ratio in the grapes decreased in the order Control $>$ V3 Guild > V2 Lumax 358 SK > V1 Pledge 50 VP.

Grapes of all experimental variants from 2017 surpassed the control in titratable acids, in 2018 the control was exceeded by V1 and V3, and in 2019 - only by V1.

The gradation in the alcoholic concentration of the wines was in correlation with the established sugar accumulation in the grapes.

The wines from the 2017 had the highest SFE. In 2017 and 2018, with the exception of V1, the other variants exceeded the control quantitatively, while in 2019 it contained the most SFE.

The mean rate of TPC in wines increased in the order Control < V1 Pledge $50 \mathrm{VP}<\mathrm{V} 2$ Lumax 358 SK < V3 Guild. In the wines from the
2018 and 2019, the control had the lowest content of phenols. In 2017 only the variant treated with Guild exceeded the control.

In 2018 and 2019, the lowest value of anthocyanins was reported in the control, and the highest in $\mathrm{V} 1$, treated with the herbicide Pledge 50 VP. In 2017, only the variant V3 treated with Guild superior the control.

No negative effect of the tested herbicides in the vineyard in the dose in which they were applied was established on the organoleptic profile of the obtained wines and they did not give them an atypical aromas or flavors.

\section{Conflict of Interest}

The authors declare that there is no conflict of interest.

\section{References}

Alcorta, M., Fidelibus, M., Steenwerth, K., \& Shrestha, A. (2011). Competitive effects of glyphosate-resistant and glyphosate-susceptible horseweed (Conyza canadensis) on young grapevines (Vitis vinifera). Weed Science, 59(4), 489-494. https://doi.org/10.1614/WS-D-10-00186

Anonymous (2016). The effect of glyphosate on the chemical composition of grapes and wine: Implications for grape and wine quality. http://www.academicwino.com/2016/07/glyphosate-grapes-wine-quality.html/.

Atanasov, P., Katerova, L., Todorova, M., \& Haygarov, V. (2005). Effect of some fungicides applied in viticulture on alcoholic fermentation and wine quality. (in Bulgarian). Scientific Researches of the Union of Scientists in Bulgaria - Plovdiv, Series C. Technics and Technologies, 5, Balkan Conference of Young Scientists, 16-18 June, Plovdiv, Bulgaria, 552-557.

Bakalivanov, D. (1982). Soil - microbiological aspects of herbicide pollution (in Bulgarian). Publishing House Zemizdat, Sofia, Bulgaria, p. 207.

Basinger, N. T., Jennings, K. M., Monks, D. W., \& Mitchem, W. E. (2019). Effect of rate and timing of indaziflam on 'Sunbelt' and muscadine grape. Weed Technology 33(2), 380-385. https://doi.org/10.1017/wet.2018.117

Caboni, P., \& Cabras, P. (2010). Pesticides' influence on wine fermentation. Advances in Food and Nutrition Research, 59, 43-62. https://doi.org/10.1016/S1043-4526(10)59002-8

Cabras P., \& Angioni, A. (2000). Pesticide residues in grapes, wine and their processing products. Journal of Agricultural and Food Chemistry, 48(4), 967-973. https://doi.org/10.1021/jf990727a

Chidi, B.S., Bauer, F.F., \& Rossouw, D. (2018). Organic acid metabolism and the impact of fermentation practices on wine acidity: A review. South African Journal of Enology and Viticulture, 39(2), 1-15. https://dx.doi.org/10.21548/39-2-3164

Dermency, H., \& Gasquez, J. (1990). Resistances auh herbicides shez les mouvaises herbes. Agronomie, 10(6), 457 $-472$.

Donnini, S., Tessarin, P., Ribera-Fonseca, A., Di Foggia, M., Parpinello, G. P., \& Rombolà, A. D. (2016). Glyphosate impacts on polyphenolic composition in grapevine (Vitis vinifera L.) berries and wine. Food Chemistry, 213, 26-30. https://doi.org/10.1016/j.foodchem.2016.06.040

Encheva, H. (1997). Influence of different systems of leached black soils treatment on the soil environment and the vine plant (in Bulgarian). PhD Thesis, Institute of Viticulture and Enology, Pleven, Bulgaria, p. 165.

Hatzidimitriou, E., Bouchilloux, P., Darriet, P., Bugaret, Y., Clerjeau, M., Poupot, C., Medina, B., \& Dubourdieu, D. (1996). Effect of antifungal protection of grapevines using a cupric formulation on the level of maturity of grapes and the varietal aroma of Sauvignon wines. Vigne Vin, 30(3), 133-150.

Hristeva, T., Yanev, M., Bozukov, H., \& Kalinova, S. (2015). Condition of soil microbial communities when exposed to some chloroacetamide herbicides. Bulgarian Journal of Agricultural Science, 21(4), 730-735.

Ivanov, T., Gerov, S., Yankov, A., Bambalov, G., Tonchev, T., Nachkov, D., \& Marinov, M. (1979). Practicum in wine technology (in Bulgarian). Publishing House "Hristo G. Danov", Plovdiv, Bulgaria, p. 530 
Karl, A., Merwin, I. A., Brown, M. G., Hervieux, R. A., \& Vanden Heuvel, J. E. (2016). Impact of undervine management on vine growth, yield, fruit composition and wine sensory analyses of Cabernet Franc. American Journal of Enology and Viticulture, 67, 269-280. https://doi.org/10.5344/ajev.2016.15061

Katerova, L. (2007). Study of the dynamics of reduction of residual fungicides in grapes, vine leaves and their impact on alcoholic fermentation and wine quality (in Bulgarian). PhD Thesis, Institute of Viticulture and Enology, Pleven, Bulgaria, p. 160.

Lièvre-Muzard, L., Ricard, S., \& Muckensturm, N. (1998). Environnement et entretien des sols. Mise en place de pratiques compatibles avec la preservation de la qualité des eaux et du patrimoine. Phytoma La Defénse des Végétaux, 511, $20-24$.

Morozova, K., Andreotti, C., Armani, M., Cavani, L., Cesco, S., Cortese, L., \& Scampicchio, M. (2017). Indirect effect of glyphosate on wine fermentation studied by microcalorimetry. Journal of Thermal Analysis and Calorimetry, 127(2), 1351-1360. https://doi.org/10.1007/s10973-016-5891-y

Nandula, V., Reddy, K., Duke, S., \& Poston, D. (2005). Glyphosate-resistant weeds: Current status and future outlook. Outlooks on Pest Management, 16(4), 183 - 187. https://doi.org/10.1564/16aug11

Oliva, J., Cayuela, M., Paya, P., Martinez-Cacha, A., Camara, M. A., \& Barba, A. (2007). Influence of fungicides on grape yeast content and its evolution in the fermentation. Communications in Agricultural and Applied Biological Sciences, 72(2), 181-189.

Oliva, J., Mulero, J., Paya, P., Camara, M. A., \& Barba, A. (2009). Influence of several fungicides on the antioxidant activity of red wines (var. Monastrell). Journal of Environmental Science and Health, Part B, 44(6), 546-552. https://doi.org/10.1080/03601230902997758

Ortiz, J. O., Peñalver, P. P., \& Navarro, A. B. (2010). Influence of fungicide residues in wine quality. In Tech, Chapter December, 421-440, https://www.intechopen.com/chapters/12396. https://doi.org/10.5772/13174

Popov, V., Kostadinova, P., Velcheva, I., \& Stavreva, P. (2009). Stomps and Nirvana herbicides and soil fauna. (in Bulgarian). Agriculture Plus, 4, 42-44.

Saladin, G., Magné, C., \& Clément, C. (2003). Stress reactions in Vitis vinifera L. following soil application of the herbicide flumioxazin. Chemosphere, 53(3), 199-206. https://doi.org/10.1016/S0045-6535(03)00515-0

Shiavon, M. (1998). L'eau et les produits phytosanitaires. Mécanismes de dispersion et de transfert selon les conditions climatiques et selon le produit. Phytoma La Defénse des Végétaux, 511, 16 - 19.

Shrestha, A., Hanson, B., Fidelibus, M., \& Alcorta, M. (2010). Growth, phenology, and intraspecific competition between glyphosate-resistant and glyphosate-susceptible horseweeds (Conyza canadensis) in the San Joaquin Valley of California. Weed Science, 58(2), 147-153. https://doi.org/10.1614/WS-D-09-00022.1

Tourte, L., Smith, R., Bettiga, L., Bensen, T., Smith, J. \& Salm, D. (2008). Post-emergence herbicides are cost effective for vineyard floor management on the Central coast. California Agriculture, 62(1), 19-23. https://doi.org/10.3733/ca.v062n01p19

Trifonova, P., Spasov, H., Todorova, M., Bambalov, K., \& Stoyanov, N. (2004). Influence of some fungicides on the propagative capacity and fermentation activity of wine yeast (in Bulgarian). Viticulture and Winemaking Journal, 2, 48-52.

Vallejo, B., Picazo, C., Orozco, H., Matallana, E., \& Aranda, A. (2017). Herbicide glufosinate inhibits yeast growth and extends longevity during wine fermentation. Scientific Reports, 7, https://doi.org/10.1038/s41598$\underline{017-12794-6}$

Yankov, A. (1992). Wine making technology (in Bulgarian). Publing House Zemizdat, Sofia, Bulgaria, p. 355.

Yoncheva, T., Katerova, L., \& Todorova, M. (2005). Study of the influence of some fungicides on alcoholic fermentation and wine quality (in Bulgarian). Scientific Researches of the Union of Scientists in Bulgaria Plovdiv, Series C. Technics and Technologies, 5, Balkan Conference of Young Scientists, 16-18 June, Plovdiv, Bulgaria, 546-551.

Yoncheva, T., Lyubenova, T., \& Haygarov, V. (2006). Study of the influence of some insecticides on the wine quality produced from Cabernet Sauvignon grape variety (in Bulgarian). Food Processing Industry Magazine, 9, 1417.

Zaller, J. G., Cantelmo, C., Dos Santos, G., Muther, S., Gruber, E., Pallua, P., Mandl, K., Friedrich, B., Hofstetter, I., Schmuckenschlager, B., \& Faber, F. (2018). Herbicides in vineyards reduce grapevine root mycorrhization and alter soil microorganisms and the nutrient composition in grapevine roots, leaves, xylem sap and grape juice. Environmental Science and Pollution Research, 25, 23215-23226. https://doi.org/10.1007/s11356-018-2422-3 